\title{
SELEKSI CALON PENERIMAAN SISWA BARU DENGAN METODE SIMPLE ADDITIVE WEIGHTING (STUDI KASUS: SMPIT CORDOVA SAMARINDA)
}

\author{
Heliza Rahmania Hatta ${ }^{1)}$, Iis Andriani ${ }^{2)}$, Dyna Marisa Khairina ${ }^{3)}$, Septya Maharani ${ }^{4)}$ \\ ${ }^{1,2,3,4}$ Program Studi Ilmu Komputer, FKTI, Universitas Mulawarman \\ E-mail : heliza_rahmania@yahoo.com ${ }^{1)}$,dyna.ilkom@gmail.com ${ }^{2)}$, iisandriani@ rocketmail.com ${ }^{3)}$, \\ septyamaharani@gmail.com ${ }^{4)}$
}

\begin{abstract}
ABSTRAK
Sekolah Menengah Pertama Islam Terpadu (SMPIT) Cordova merupakan salah satu sekolah swasta di Samarinda yang berbasis pendidikan islam, dimana akreditas dari sekolah tersebut sampai tahun 2017 adalah A. Sehingga memberikan pengaruh terhadap jumlah calon siswa baru yang mendaftar dan dari tahun ke tahun calon siswa baru yang mendaftar melebihi kuota yang ada. Salah satu cara meningkatkan mutu Sekolah dengan membangun sebuah sistem penunjang keputusan yang dapat menyeleksi calon siswa baru untuk meminimalisir kesalahan yang dilakukan oleh panitia penyeleksi calon siswa baru Sekolah Menengah Pertama Islam Terpadu (SMPIT) Cordova Samarinda. Penelitian ini bertujuan untuk digunakan untuk membantu mengambil keputusan dalam meyeleksi calon siswa baru di SMPIT CORDOVA Samarinda menggunakan metode SAW (Simple Additive Weighting). Hasil dari penelitian ini adalah metode SAW dapat diterapkan pada studi kasus seleksi calon siswa baru di SMPIT Cordova Samarinda.
\end{abstract}

Kata Kunci: Calon, Simple Additive Weighting, Seleksi, Sistem Penunjang Keputusan, Siswa Baru

\section{PENDAHULUAN \\ Sekolah Menengah Pertama Islam Terpadu (SMPIT)} Cordova merupakan salah satu sekolah swasta di Samarinda yang berbasis pendidikan islam, dimana akreditas dari sekolah tersebut sampai tahun 2017 berakreditas A. Dengan hasil akreditas A, SMPIT Cordova Samarinda dapat memberikan informasi yang akurat tentang pelayanan pendidikan yang ditawarkan bagi masyarakat khususnya orang tua peserta didik dalam membuat keputusan dan pilihan yang tepat dalam memilih sekolah. Terlihat dari jumlah pendaftar dari tahun ke tahun selalu melebihi kuota yang sudah disediakan yaitu 140 siswa ditahun ajaran baru. Tahun 2014/2015 pendaftar 168 orang, tahun 2015/2016 pendaftar 173 orang dan tahun 2016/2017 179 orang (Hasil wawancara).

Manfaat yang diberikan dari hasil akreditas tersebut tidak hanya dari sisi daya tampung yang melebihi kuota. Namun dari pihak sekolah pun dapat sebagai acuan dalam upaya peningkatan mutu dan rencana pengembangan sekolah tersebut. Melihat dari banyaknya pendaftar dan salah satu cara bagaimana meningkatkan mutu Sekolah, maka perlu dibangun sebuah sistem pendukung keputusan dengan yang dapat menseleksi calon siswa baru untuk meminimalisir kesalahan yang dilakukan oleh panitia penyeleksi calon siswa baru SMPIT Cordova Samarinda.

Sistem pendukung keputusan dapat menggunakan beberapa metode dan salah satu metodenya adalah metode Simple Additive Weighting (SAW). Dimana Metode SAW merupakan metode Multiple Attribute
Decision Making (MADM), dimana langkah penyelesaian alternatifnya lebih pendek namun akan tetap menghasilkan keputusan optimal dalam menentukan alternatif terbaik dari berbagai alternatif berdasarkan kriteria tertentu (Ariani, 2013) (Harpad, 2018).

Metode SAW dapat menunjukkan lahan yang terbaik untuk tanaman sawit (Hatta dkk, 2017). Metode SAW juga telah digunakan dalam penelitian (Murdianto dkk, 2016), dengan hasil akhir penelitian sistem dapat menyeleksi karyawan terbaik sesuai ketentuan dengan melakukan perhitungan berdasarkan metode SAW. Dan metode SAW dapat mendiagnosa penyakit pada kelinci (Ramadiani dkk, 2017). Dan beberapa penelitian lain yang menggunakan metode SAW seperti (Lailiyah, 2016) (Oleh karena sistem pendukung keputusan dengan metode SAW dapat digunakan untuk membantu panitia penyeleksi calon siswa baru SMPIT Cordova Samarinda untuk menentukan siswa baru di SMPIT Cordova Samarinda.

\section{RUANG LINGKUP}

Penelitian ini dilakukan di SMPIT Cordova Samarinda untuk seleksi calon siswa baru. Penelitian ini untuk memberikan rekomendasi kepada sekolah dalam menseleksi siswa baru yang akan masuk. 


\section{BAHAN DAN METODE}

Seleksi calon siswa baru pada SMPIT CORDOVA Samarinda menggunakan sistem pendukung keputusan, dimana metode yang digunakan adalah metode SAW. Kriteria-kriteria yang digunakan untuk jalur prestasi dan jalur reguler yaitu raport, tes akademik, tes tahsin, dan tes tahfizh. Data yang yang digunakan dalam metode SAW adalah nilai rating kecocokan untuk setiap alternatif pada setiap kriteria.

\subsection{Sistem Pendukung Keputusan}

Sistem Pendukung Keputusan atau sering disebut Decision Support System (DSS) adalah sistem berbasis model yang terdiri dari prosedur-prosedur dalam pemrosesan data dan pertimbangannya untuk membantu manajer dalam mengambil keputusan. Agar berhasil mencapai tujuannya maka sistem tersebut harus sederhana, mudah untuk dikontrol, mudah beradaptasi lengkap dengan hal-hal penting dan mudah berkomunikasi dengannya. Secara implisit juga berarti bahwa sistem ini harus berbasis komputer dan digunakan sebagai tambahan dari kemampuan penyelesaian masalah dari seseorang (Turban, 2005). Sistem Pendukung Keputusan (SPK) merupakan sistem yang memiliki beberapa alur dalam pemrosesan data dan pemberian keputusan kepada pengguna atau user. Oleh karena itu, sistem SPK dibuat atau dibangun secara sederhana dan user friendly. Dengan menggunakan SPK diharapkan dapat memberikan rekomendasi yang terbaik bagi pengguna atau user (Hatta dkk, 2017) (Khairina dkk, 2015) (Suryani dkk, 2017) (Hatta dkk, 2016) (Khairina dkk, 2016).

\subsection{Tahapan Pengambilan Keputusan}

Untuk menghasilkan keputusan yang baik dlaam beberapa tahapan proses yang harus dilalui dalam pengambilan keputusan keputusan. Dikutip dari (Kurniasih, 2017), proses pengambilan keputusan melalui beberapa tahap berikut:

1. Tahap Penelurusan (intelligence)

Tahap ini pengambil keputusan empelajari kenyataan yang terjadi, sehingga kita bisa mengidentifikasi masalah yang terjadi biasanya dilakukan analisis dari sistem ke subsistem pembentukannya sehingga didapatkan keluaran berupa dokumen pernyataan masalah.

\section{Tahap Desain}

Dalam tahap ini pengambilan keputusan menentukan, mengembangkan dan menganalisi semua pemecahan yang mungkin yaitu melalui pembuatan model yang bisa mewakili kondisi nyata masalah. Dari tahapan ini didapatkan keluaran berupa dokumen alternatif solusi.

\section{Tahap Choice}

Dalam tahap ini pengambil keputusan memilih salah satu alternatif pemecahan yang dibuat pada tahap desain yang dipandang sebagai aksi yang paling tepat untuk mengatsi maslaah yang sedang dihadapi. Dari tahap ini didapatkan dokumen salusi dan rencana implementasi.

\section{Tahap Implementasi}

Pengambil keputusan menjalankan rangkaian aksi pemecahan yang dipilih di tahap choice. Implementasi yang sukses ditandai dengan terjawabnya masalah yang dihadapi, sementara kegagalan ditandai masih adanya masalah yang sedang dicoba untuk diatasi. Dari tahap ini didapatkan laporan pelaksanaan solusi dan hasilnya.

\subsection{Komponen-Komponen Sistem Pendukung Keputusan}

Aplikasi sistem pendukung keputusan bisa terdiri dari beberapa subsistem, yaitu :

1. Subsistem manajemen data

Subsistem manajemen data memasukkan satu database yang berisi data relevan untuk suatu situasi dan dikelola oleh perangkat lunak yang disebut sistem manajemen database (DBMS / Data Base Management System). Subsistem manajemen data bisa di interkonekasikan dengan data warehouse perusahaan, suatu repositori untuk data perusahaan yag relevan dengan pengambilan keputusan.

2. Subsistem manajemen modal

Merupakan paket perangkat lunak yang memasukkan model keuangan, statistik, ilmu manajemen, atau model kuantitatif lain yng memberikan kapabilitas analitik dan manajemen perangkat lunak yang tepat. Bahasa-bahasa pemodelan untuk membangun model-model kustom juga dimasukkan. Perangkat lunak itu sering disebut sistem manajemen basis model (MBMS). komponen tersebut bisa dikoneksikan ke penyimpanan korporat atau eksternal yang ada pada model.

3. Subsistem antar pengguna

Pengguna berkomunikasi dengan dan memerintahkan sistem pendukung keputusan melalui subsistem tersebut. Pengguna adalah bagian yang dipertimbangkan dari sistem. Para peneliti menegaskan bahwa beberapa kontribusi unik dari sistem pendukung keputusan berasal dari interaksi yang intensif antara komputer dan pembuat keputusan

4. Subsistem mnajemen berbasis pengetahuan

Subsistem tersebut mendukung semua subsistem lain atau bertindak langsung sebagai suatu komponen independen dan bersifat operasional. Selain memberikan inteligensi untuk memperbesar pengetahuan si pengambil keputusan. Subsistem tersebut bisa diinterkoneksikan dengan reposotori pengetahuan perusahaan (bagian dari sistem manajemen pengetahuan), yang kadang-kadang disebut basis pengetahuan operasional.

\subsection{Multi-Atribut Decision Making (MADM)}

Metode SAW merupakan metode MADM yang paling sederhana dan paling banyak digunakan. Metode ini juga metode yang paling mudah untuk diaplikasikan, karena mempunyai algoritma yang tidak terlalu rumit.

Metode SAW sering juga dikenal sebagai metode penjumlahan berbobot. Konsep dasar metode SAW adalah mencari penjumlahan terbobot dari rating kinerja pada setiap alternatif pada semua atribut. Metode SAW 
membutuhkan proses normalisasi matriks keputusan (X) ke suatu skala yang dapat diperbandingkan dengan semua rating alternatif yang ada.

Ada beberapa metode yang dapat digunakan untuk meyelesaikan masalah MADM antara lain :

1. Simple Additive Weighting (SAW)

2. Weighted Product (WP)

3. Elimination and Choise Expressing Reality (ELECTRE)

4. Technique for Order Preference by Similarity to Ideal Solution (TOPSIS)

5. Analytic Hierarchy Process (AHP)

\subsection{Metode SAW}

Metode SAW dikenal juga dengan metode penjumlahan terbobot. Konsep dasar metode SAW adalah mencari penjumlahan terbobot dari rating kinerja pada setiap alternatif pada semua atribut. Metode SAW membutuhkan proses normaslisasi matriks keputusan (X) ke suatu skala yang dapat diperbandingkan dengan semua rating alternatif yang ada. Metode SAW harus memiliki beberapa alternatif (A), Kriteria (C), dan berat (Weight) yang mempunyai bobot ketentuan.

Berikut langkah-langkah pada metode SAW:

1. Pengambilan keputusan memberikan bobot preferensi yang akan diproses dalam perankingan dengan matriks yang telah ternormalisasi

$$
X=\left[\begin{array}{cccc}
X_{11} & X_{12} & \cdots & X_{I n} \\
X_{21} & X_{22} & \cdots & X_{2 n} \\
\vdots & \vdots & & \\
X_{m 1} & X_{m 2} & \cdots & X_{m n}
\end{array}\right]
$$

$\mathrm{W}=\{\mathrm{W} 1, \mathrm{~W} 2, \ldots . ., \mathrm{Wn}\}$

2. Matriks dibentuk dari tabel kecocokan Alternatif (A) dan Kriteria (C)

3. Setelah mendapatkan nilai matriks $X$, maka dilakukan normalisasi matriks berdasarkan persamaan berikut :

$r_{i j}= \begin{cases}\frac{x_{i j}}{\operatorname{Max}_{i}} & \text { Jika } \mathrm{j} \text { adalah atribut keuntungan (benefit) } \\ \operatorname{Min}_{i} x_{i j} & \text { Jika j adalah atribut biaya (cost) }\end{cases}$

Keterangan :

$r_{i j}=$ nilai rating kinerja alternatif

$x_{i j}=$ nilai atribut yang dimiliki dari setiap kriteria

$\operatorname{Maxx}_{i j}=$ nilai terbesar sari setiap kriteria

$\operatorname{Minx}_{i j}=$ nilai terkecil dari setiap kriteria

Dimana $r_{i j}$ adalah rating kinerja ternormalisasi dari alternatif Ai pada atribut $\mathrm{Cj}$ : $\mathrm{i}=1,2, \ldots . ., \mathrm{m}$ dan $\mathrm{j}=$
$1,2, \ldots, n$

4. Setelah diperoleh matriks ternormalisasi (R), maka dibuat proses perankingan dengan nilai preferensi untuk setiap alternatif $\left(\mathrm{V}_{\mathrm{i}}\right)$ diberikan sebagai berikut:

$V_{i}=\sum_{j=1}^{n} w_{j} r_{i j}$

Keterangan :

$\mathrm{V}_{\mathrm{i}}=$ rangking untuk setiap alternatif

$\mathrm{W}_{\mathrm{j}}=$ nilai bobot dari setiap kriteria

$\mathrm{r}_{\mathrm{ij}}=$ nilai rating kinerja ternormalisasi

Nilai $V_{i}$ yang paling besar mengindikasi bahwa alternatif $\mathrm{Ai}$ lebih terpilih sebagai alternatif terbaik, sehingga alternatif (Ai) yang memiliki nilai $V_{i}$ terbesar yang terpilih.

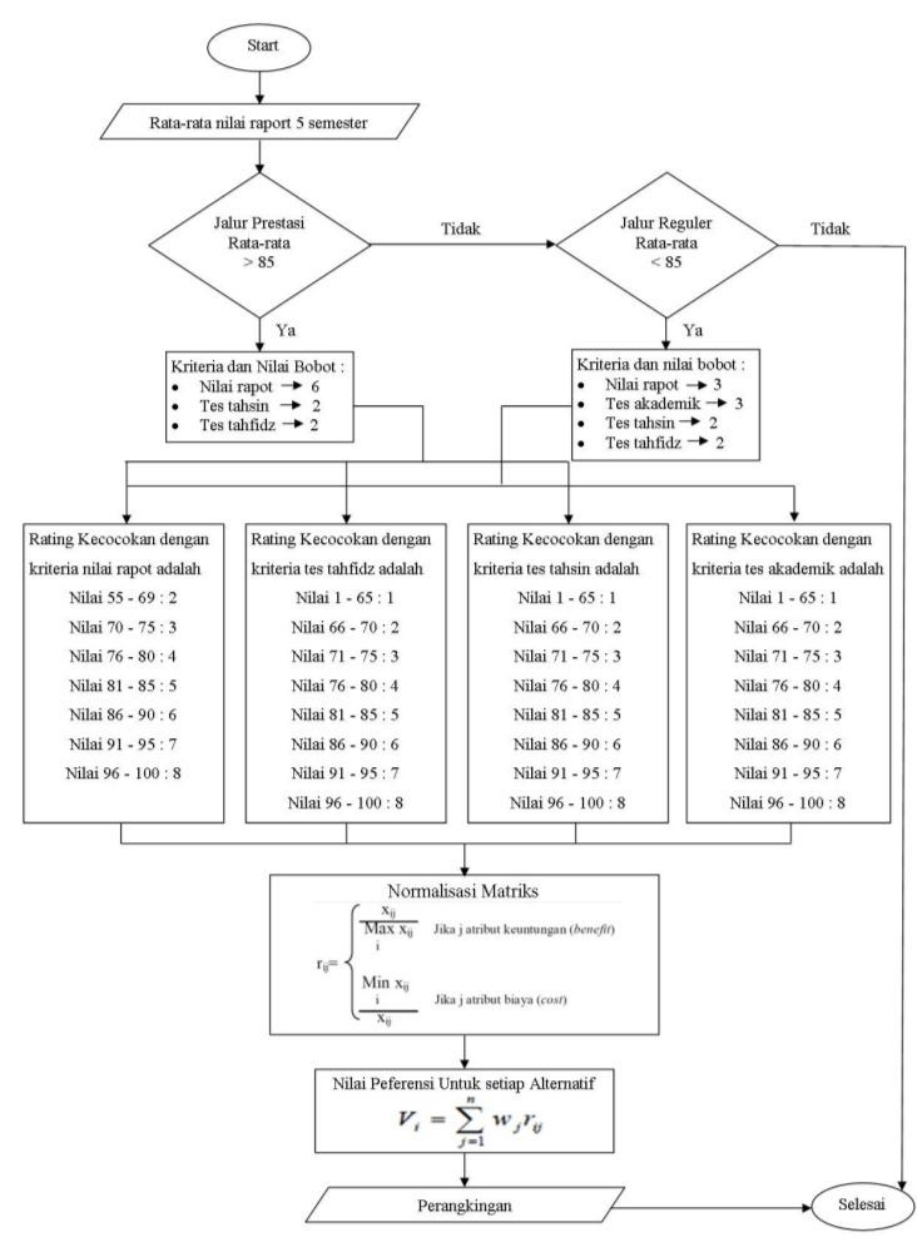

\section{Gambar 1. Flowchart Proses Seleksi Calon Penerimaan Siswa Baru di SMPIT Cordova Samarinda Dengan Metode SAW}

\subsection{Tahapan Penelitian}

Identifikasi dan Analisis Sistem Sesuai dengan latar belakang yang ada, maka penelitian ini diharapkan dapat membentuk sistem baru yang mampu memberikan solusi 
yang tepat, mudah digunakan dan membantu dalam seleksi penerimaan calon siswa baru. Tahapan penelitian yaitu dengan memasukkan nilai pembobotan, melihat dari rata-rata raport selama 5 semester yang menjadi patokan kriteria mana yang akan dipilih, dilanjutkan dengan proses perhitungan SAW. Menghitung penilaian terhadap setiap altenatif menggunakan fungsi yang telah ada, dan proses terakhir yaitu memilih alternatif dengan nilai tertinggi. Setelah semua data diketahui akan dilanjutkan dengan tahap perancangan sistem. Gambar 1 merupakan Flowchart Proses Seleksi Calon Penerimaan Siswa Baru di SMPIT Cordova Samarinda Dengan Metode SAW. Dan gambar 2 merupakan arsitektur keseluruhan sistem pendukung keputusan menyeleksi siswa baru SMPIT Cordova Smarinda.

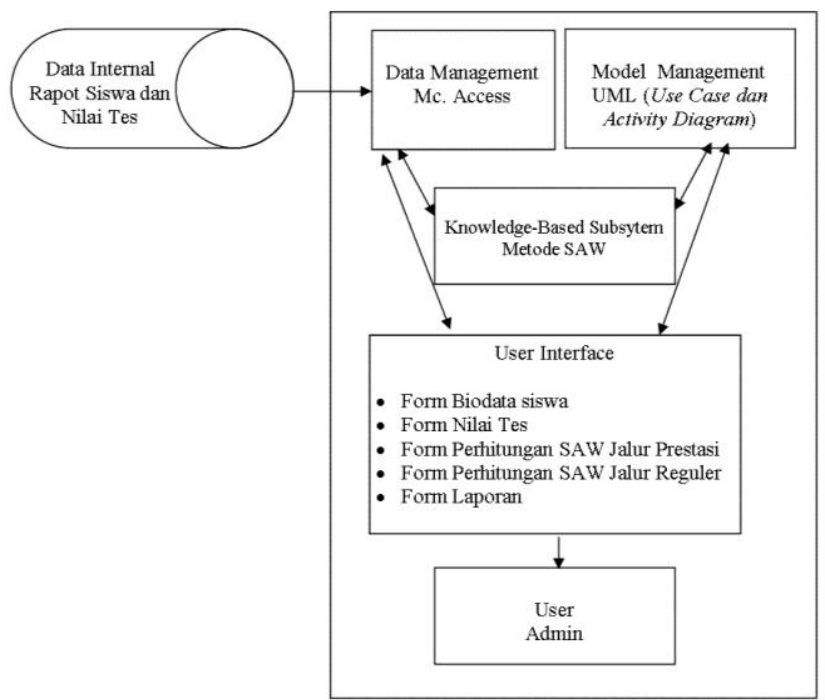

\section{Gambar 2. Arsitektur SPK Seleksi Calon Penerimaan Siswa Baru Dengan Metode SAW Pada SMPIT Cordova Samarinda}

Perancangan use case diagram merupakan tahap awal dan utama dalam proses pengembangan sistem, dimana dalam tahapan ini dijelaskan dan didefinisikan fungsifungsi serta fitur-fitur apa saja yang dapat disediakan oleh sistem. Use case diagram mempunyai satu aktor, yaitu panitia penyeleksi. Pada Gambar 3 terlihat bahwa tiga belas case, dimana semua case ditujukan untuk admin. Case admin sendiri harus melakukan login terlebih dahulu sebelum masuk halaman menu utama. Disini guru berfungsi untuk me-manage data seperti menambah, menghapus, dan mengubah data siswa, nilai hasil perhitungan, serta mencetak laporan.

\section{PEMBAHASAN}

Data seperti kriteria, bobot dan alternatif didapat dari SMPIT Cordova Samarinda. Kriteria dan bobot yang digunakan dalam menyeleksi calon siswa baru adalah sebagai berikut :
Kirteria nilai bobot Jalur Reguler :

1. Raport $=3$

2. Tes akademik $=3$

3. Tes $\operatorname{tah} \sin =2$

4. Tes tahfidz $=2$

Kirteria nilai bobot Jalur Prestasi :

1. Raport $=6$

2. Tes tahsin $=2$

3. Tes tahfidz $=2$

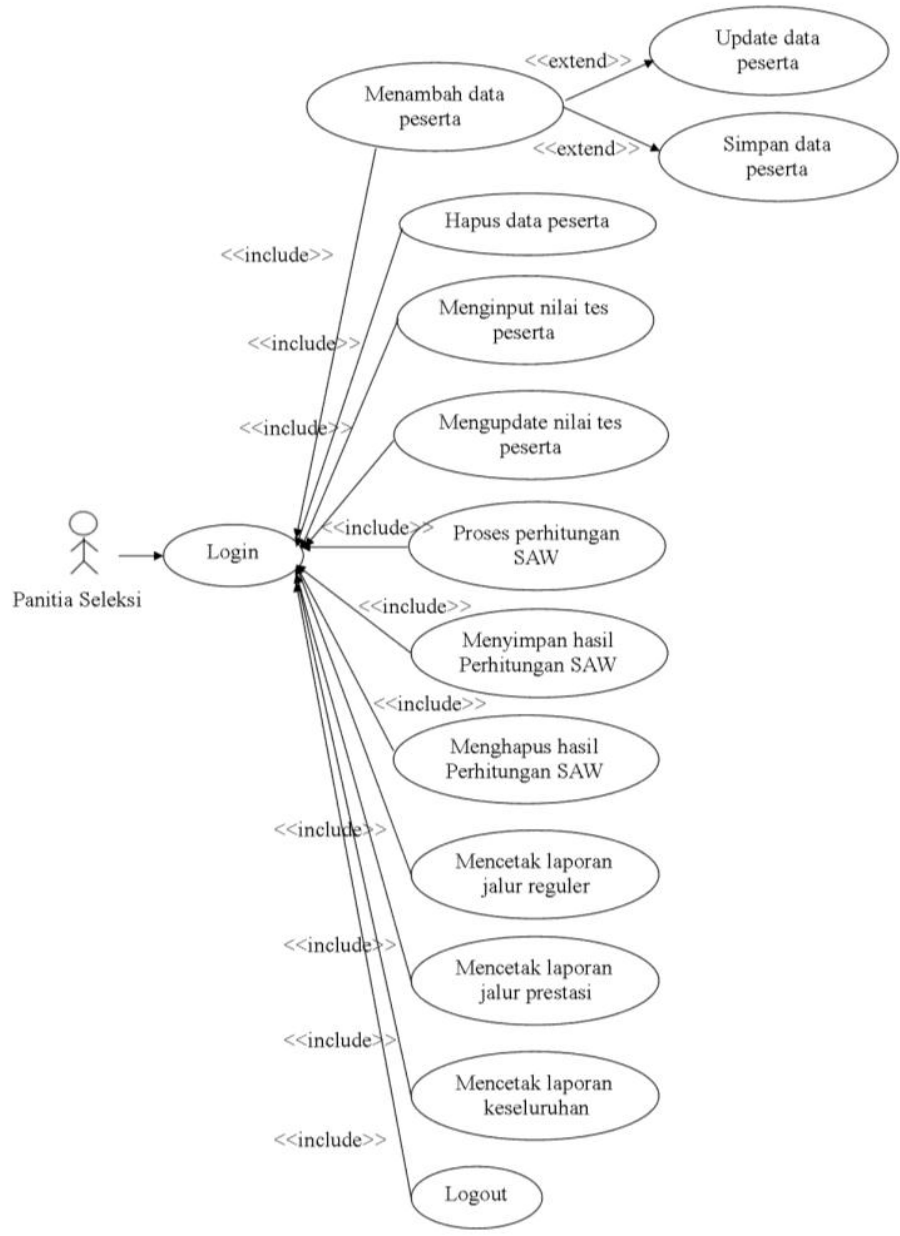

Gambar 3. Use Case Diagram Sistem

Nilai rapot yang diambil dari kelas 4-6 SD, kelas 4 dan 5 diambil semester 1 sampai 2 sedangkan kelas 6 diambil hanya semester 1 saja. Karena SMPIT CORDOVA Samarinda membuka pendaftaran untuk siswa baru lebih awal dibandingkan dengan sekolah lain di Samarinda. Sehingga dikelas 6 hanya semster 1 saja yang diambil. Kemudian dari jumlah 5 semester itu ditotal kemudian dirata-ratakan dan dibagi 5. Jika setelah dibagi 5 hasilnya $>85$ maka calon siswa tersebut masuk seleksi penerimaan siswa lewat jalur prestasi dan akan mengikuti tes tahsin dan tes tahfidz, sedangkan jika nilainya < 85 maka akan masuk jalur reguler dan akan mengikuti tes akademik, tahsin dan tahfidz. Dimana yang 
dibahas sistemnya adalah untuk jalur reguler. Untuk rating kecocokan kriteria nilai raport dapat dilihat pada Tabel 1. Sedangkan rating kecocokan kriteria nilai tes akademik, nilai tes tahsin, dan nilai tes tahfidz memiliki nilai yang sama, dapat dilihat pada Tabel 2 .

\section{Tabel 1. Nilai rating kecocokan untuk raport}

\begin{tabular}{|c|c|}
\hline Nilai Raport & Nilai \\
\hline$<55$ & 1 \\
\hline $55-69$ & 2 \\
\hline $70-75$ & 3 \\
\hline $76-80$ & 4 \\
\hline $81-85$ & 5 \\
\hline $86-90$ & 6 \\
\hline $91-95$ & 7 \\
\hline $96-100$ & 8 \\
\hline
\end{tabular}

Tabel 2. Rating kecocokan untuk tes akademik, tes tahsin, dan tes tahfidz

\begin{tabular}{|c|c|}
\hline Nilai Tes Akademik & Nilai \\
\hline$<=65$ & 1 \\
\hline $66-70$ & 2 \\
\hline $71-75$ & 3 \\
\hline $76-80$ & 4 \\
\hline $81-85$ & 5 \\
\hline $86-90$ & 6 \\
\hline $91-95$ & 7 \\
\hline $96-100$ & 8 \\
\hline
\end{tabular}

Tabel 3. Rata-rata nilai raport 5 semester

\begin{tabular}{|c|c|c|c|c|c|c|}
\hline Nama & $\begin{array}{c}\text { Kelas } \\
\mathbf{4} \text { smtr } \\
\mathbf{1}\end{array}$ & $\begin{array}{c}\text { Kelas } \\
\mathbf{4} \text { smtr } \\
\mathbf{2}\end{array}$ & $\begin{array}{c}\text { Kelas } \\
\mathbf{5} \text { smtr } \\
\mathbf{1}\end{array}$ & $\begin{array}{c}\text { Kelas } \\
\mathbf{5} \text { smtr } \\
\mathbf{2}\end{array}$ & $\begin{array}{c}\text { Kelas } \\
\mathbf{6} \text { smtr } \\
\mathbf{1}\end{array}$ & $\begin{array}{c}\text { Rata- } \\
\text { rata }\end{array}$ \\
\hline $\mathrm{A}$ & 70 & 70 & 72,6 & 70 & 70 & 70,52 \\
\hline $\mathrm{B}$ & 74 & 70 & 73 & 71 & 83 & 74,2 \\
\hline $\mathrm{C}$ & 85 & 82,3 & 84 & 85 & 84 & 84,06 \\
\hline $\mathrm{D}$ & 78 & 77 & 70,2 & 81 & 84 & 78,04 \\
\hline $\mathrm{E}$ & 83 & 81 & 80 & 82,7 & 84 & 82,14 \\
\hline
\end{tabular}

Tabel 4. Data calon siswa baru

\begin{tabular}{|c|c|c|c|c|}
\hline Nama & $\begin{array}{c}\text { Nilai } \\
\text { Raport }\end{array}$ & $\begin{array}{c}\text { Tes } \\
\text { Akademik }\end{array}$ & $\begin{array}{c}\text { Tes } \\
\text { Tahsin }\end{array}$ & $\begin{array}{c}\text { Tes } \\
\text { Tahfidz }\end{array}$ \\
\hline A & 70.52 & 46 & 70 & 73 \\
\hline B & 74.2 & 68 & 70 & 70 \\
\hline C & 84.06 & 84 & 78 & 70 \\
\hline D & 78.04 & 64 & 74 & 79 \\
\hline E & 82.14 & 58 & 80 & 93 \\
\hline
\end{tabular}

Tabel 5. Rating kecocokan setiap alternatif pada setiap kriteria

\begin{tabular}{|c|c|c|c|c|}
\hline Alternatif & C1 & C2 & C3 & C4 \\
\hline A & 3 & 1 & 2 & 3 \\
\hline B & 3 & 2 & 2 & 2 \\
\hline C & 5 & 5 & 4 & 2 \\
\hline D & 4 & 1 & 3 & 4 \\
\hline E & 5 & 1 & 4 & 7 \\
\hline
\end{tabular}

Untuk contoh perhitungan, diambil 5 sampel dari 210 pendaftar. Langkah pertama menghitung rata-rata nilai raport dari kelas 4-6 SD setiap anak, dapat dilihat pada Tabel 3. Setelah dirata-ratakan dari kelima pendaftar, ternyata tidak ada yang > 85, maka dapat dipastikan semuanya masuk ke jalur reguler. Dan perhitungan dari kriteria maka nilai bobotnya masing-masing dapat dilihat pada Tabel 4. Dari Tabel 4 dapat dibuat tabel rating kecocokan setiap alternatif pada setiap kriteria, dapat dilihat pada Tabel 5 .

Langkah-langkah penyelesaian

1. Vektor bobot jalur reguler: $\mathrm{W}=[3 ; 3 ; 2 ; 2]$

2. Matriks keputusan nilai $\mathrm{X}$ berdasarkan kriteria bobot

$$
X=\left\{\begin{array}{llll}
3 & 1 & 2 & 3 \\
3 & 2 & 2 & 2 \\
5 & 5 & 4 & 2 \\
4 & 1 & 3 & 4 \\
5 & 1 & 4 & 7
\end{array}\right\}
$$

3. Normalisasi matrik X menggunakan Persamaan 1

$|\mathrm{C} 1| \max (3 ; 3 ; 4 ; 5 ; 5)=5$

$\mathrm{R}_{11}=3 / 5=0,6$

$\mathrm{R}_{21}=3 / 5=0,6$

$\mathrm{R}_{31}=5 / 5=1$

$\mathrm{R}_{41}=4 / 5=0,8$

$\mathrm{R}_{51}=5 / 5=1$

$|\mathrm{C} 2| \max (1 ; 2 ; 5 ; 1 ; 1)=5$

$\mathrm{R}_{12}=1 / 5=0,2$

$\mathrm{R}_{22}=2 / 5=0,4$

$\mathrm{R}_{32}=5 / 5=1$

$\mathrm{R}_{42}=1 / 5=0,2$

$\mathrm{R}_{52}=1 / 5=0,2$

|C3 $\mid \max (2 ; 2 ; 4 ; 3 ; 4)=4$

$\mathrm{R}_{13}=2 / 4=0,5$

$\mathrm{R}_{23}=2 / 4=0,5$

$\mathrm{R}_{33}=4 / 4=1$

$\mathrm{R}_{43}=3 / 4=0,75$

$\mathrm{R}_{53}=4 / 4=1$

|C4| $\max (3 ; 2 ; 2 ; 4 ; 7)=7$

$\mathrm{R}_{14}=3 / 7=0,42$

$\mathrm{R}_{24}=2 / 7=0,28$

$\mathrm{R}_{34}=2 / 7=0,28$

$\mathrm{R}_{44}=4 / 7=0,57$

$\mathrm{R}_{54}=7 / 7=1$

Dari perhitungan normalisasi didapatkan matriks ternormalisasi $\mathrm{R}$ sebagai berikut

$$
R=\left\{\begin{array}{cccc}
0,6 & 0,2 & 0,5 & 0,42 \\
0,6 & 0,4 & 0,5 & 0,28 \\
1 & 1 & 1 & 0,28 \\
0,8 & 0,2 & 0,75 & 0,57 \\
1 & 0,2 & 1 & 1
\end{array}\right\}
$$


4. Mencari alternatif terbaik menggunakan Persamaan 2

$\mathrm{V}_{1}=(0,6 \times 3)+(0,2 \times 3)+(0,5 \times 2)+(0,42 \times 2)=4,24$

$\mathrm{V}_{2}=(0,6 \times 3)+(0,4 \times 3)+(0,5 \times 2)+(0,28 \times 2)=4,56$

$\mathrm{V}_{3}=(1 \times 3)+(1 \times 3)+(1 \times 2)+(0,28 \times 2)=8,56$

$\mathrm{V}_{4}=(0,8 \times 3)+(0,2 \times 3)+(0,75 \times 2)+(0,57 \times 2)=5,5$

$\mathrm{V}_{5}=(1 \times 3)+(0,2 \times 3)+(1 \times 2)+(1 \times 2)=7,6$

$\mathrm{V}_{3}$ merupakan peringkat pertama karena memiliki nilai yang lebih besar dari nilai lain, $\mathrm{V}_{3}$ merupakan nilai preferensi dari alternatif $\mathrm{C}$. Alternatif $\mathrm{C}$ dapat dinyatakan diterima di SMPIT CORDOVA Samarinda. Dalam kasus ini yang dinyatakan diterima adalah yang memiliki nilai akhir >8 dan masih dalam kuota penerimaan siswa baru, baik untuk jalur prestasi maupun jalur reguler.

\section{KESIMPULAN}

Sistem ini dapat mempermudah panitia penyeleksi calon siswa baru dalam proses perhitungan dengan jumlah pendaftar yang banyak. Selain itu sistem ini dapat memberikan rekomendasi kepada panitia dalam menyeleksi calon siswa baru di SMPIT CORDOVA Samarinda agar dapat meminimalisir kesalahan yang terjadi walaupun hasil akhir siapa saja siswa baru yang keterima adalah hak dari pihak SMPIT CORDOVA Samarinda.

\section{SARAN}

Diharapkan untuk penelitian selanjutnya dapat membandingkan hasil penelitian dengan metode MADM lain selain metode SAW sehingga dapat diketahui metode yang paling cocok untuk kasus ini.

\section{DAFTAR PUSTAKA}

Ariani, A., Abdillah, L.A. and Syakti, F., 2013. Sistem pendukung keputusan kelayakan TKI ke luar negeri menggunakan FMADM. arXiv preprint arXiv: 1312.5162 .

Harpad, B. and Salmon, S., 2018. Penerapan Metode Ahp Dan Metode Topsis Dalam Sistem Pendukung Keputusan Pemilihan Asisten Laboratorium Komputer Pada Stmik Widya Cipta Dharma Samarinda. Sebatik, 19(1), pp.28-34.

Hatta, H.R., Khairina, D.M. and Amaliya, R., 2016. Decision Support Systems For the Selection of Outstanding Students by Using Analytic Hierarchy Proses Method (Case Study: LKP El-Rahma Samarinda). ITSMART: Jurnal Teknologi dan Informasi, 5(1), pp.1-6.

Hatta, H.R., 2017. Pemilihan Lahan Terbaik untuk Tanaman Kelapa Sawit menggunakan Metode Simple Additive Weighting. Prosiding SENIATI, 3(1), pp.14-1.

Hatta, H.R., Gunawan, B. and Khairina, D.M., 2017. Pemilihan Pemain Terbaik Futsal Dengan Metode
Simple Multi Attribute Rating Tecnique, Studi Kasus: Turnamen Futsal Di Samarinda. Jurnal Informatika, 11(1), pp.1-8.

Khairina, D.M., Ramadhani, F., Maharani, S. and Hatta, H.R., 2015, October. Department recommendations for prospective students Vocational High School of information technology with Naïve Bayes method. In 2015 2nd International Conference on Information Technology, Computer, and Electrical Engineering (ICITACEE) (pp. 92-96). IEEE.

Khairina, D.M., Asrian, M.R. and Hatta, H.R., 2016, October. Decision support system for new employee recruitment using weighted product method. In 2016 3rd International Conference on Information Technology, Computer, and Electrical Engineering (ICITACEE) (pp. 297-301). IEEE.

Kurniasih, D.L., 2017. Sistem pendukung keputusan pemilihan laptop dengan metode TOPSIS. Pelita Informatika: Informasi dan Informatika, 3(2).

Lailiyah, S., Salmon, S. and Haeda, N., 2016. Sistem Pendukung Keputusan Menentukan Anak Asuh Pena Prestasi Menggunakan Metode Saw (Simple Additive Weighting) Pada Lembaga Amil Zakat Dana Peduli Ummat Kalimantan Timur. Sebatik, 15(1), pp.25-30.

Murdianto, H., Khairina, D.M. and Hatta, H.R., 2016, September. Sistem Pendukung Keputusan Pemilihan Karyawan Terbaik Per Triwulan PT. Cahaya Fajar Kaltim PLTU Embalut Tanjung Batu Menggunakan Metode Simple Additive Weighting. In Prosiding SAKTI (Seminar Ilmu Komputer dan Teknologi Informasi) (Vol. 1, No. 1, pp. 24-29).

Ramadiani, Marissa, D., Jundillah, M.L. and Hatta, H.R., 2018. Simple Additive Weighting to Diagnose Rabbit Disease. In E3S Web of Conferences (Vol. 31, p. 10002). EDP Sciences.

Suryani, M.A.I., Arifin, Z. and Hatta, H.R., 2017. Pemilihan Paket Wisata Menggunakan Metode Analytical Hierarchy Process (AHP). Informatika Mulawarman: Jurnal Ilmiah Ilmu Komputer, 12(2), pp.64-68.

Turban, Efraim. 2005. Decision Support System and Intelligent, edisi Bahasa Indonesia jilid 1. Yogyakarta: Penerbit Andi.

\section{UCAPAN TERIMA KASIH}

Penelitian ini telah dibiayai oleh Fakultas Ilmu Komputer dan Teknologi Informasi, Universitas Mulawarman,

berdasarkan Keputusan Rektor Universitas Mulawarman Nomor: 1985/SK/2018.

Terima kasih kami ucapkan kepada Ibu Ika Agustina, S.Kom, selaku guru mata pelajaran TIK (Teknik Infromasi dan Komunikasi) dan Panitia Penerimaan Siswa Baru SMPIT CORDOVA Samarinda, yang telah memberikan data untuk penelitian ini. 